\title{
A systematic review of investment opportunity set and dividend policy
}

\author{
Hamad Raza*, Syed Muhammad Ahmad Hassan Gillani², \\ Muhammad Ishfaq ${ }^{3}$, Saif ul Nazir ${ }^{4}$ \\ 1,2Azman Hashim International Business School (AHIBS), Universiti Teknologi Malaysia (UTM), 81310, Johor Bahru,
Johor, Malaysia.
3,4Riphah International University, Faisalabad Campus, Pakistan.
}

*Corresponding Author email: hamad_raza@hotmail.co.uk

Submission: 12 September 2020

Revised: 08 December 2020

Accepted: 02 January 2021

\begin{abstract}
There are numerous factors that affects corporate dividend policy and investment opportunity set is among one of the significant factors. Investor are interested to make investments in those firms, which provide benefit and prosperity to shareholders and investors. As investors expect return on investment in the form of dividends. The present study aimed to overview the overall literature published on the relationship of investment opportunity set and dividend policy. For this purpose, articles are selected from the literature published on Scopus and Google Scholar databases. The research methodology adopted the stepwise screening procedure of the PRISMA guidelines and final 28 studies are included for the systematic literature review. After critically analyzing the selected studies, the findings suggests that investment opportunity set is a factor that significantly effect dividend policy. Moreover, the result demonstrates that the interest in the topic of investment opportunity set and its influence on dividend policy is growing. Furthermore, the trend of researchers and academicians to publish their research work is more towards journals-based articles rather than conference articles.
\end{abstract}

Keywords: Dividend policy, Investment Opportunity Set, Systematic Review, Investments

\section{INTRODUCTION}

One of the most significant corporate finance issues that can be intently linked to, and interrelate with majority of the investment decisions that corporations make is dividend payout policy. Allen and Michaely (1995) stated that understanding and setting an appropriate dividend policy is an important and crucial assignment for the management as it has a foremost effect on firm's share price and several other areas like capital budgeting, mergers and acquisitions, capital structure, and asset valuation. The dividend payout decisions of corporations can also be influenced by various factors including firm's risk, profitability, size and ownership. Although, Ooi (2001) has already identified that major decision faced by firm's management is dividend payout policy but it ruins one of the enigma in the field of corporate finance. The emerging consent is already prevailing that there is no particular explanation of dividends. This observation has been supported by Brook, Charlton Jr, and Hendershott (1998) which say that there is no basis to consider that single goal determines the firm's dividend payout policy. Many researchers have given attention on empirical research to prove the link between dividend payout and investment 
opportunities set (Aivazian, Booth, \& Cleary, 2003; Pruitt \& Gitman, 1991). Though, no clear link is found concerning this issue (Abor \& Bokpin, 2010).

The primary motive of this article is to provide a systematic review of literature that emphases on the association between investment opportunity set and dividend policy. The significance of present study is to gauge the researchers' work related to this topic. The current article is organized as follows. First part involves screening of literature articles based on inclusion / exclusion criteria and following the PRISMA flowchart. The second part comprises of analysis and the last part discusses the conclusion.

\section{REVIEW OF LITERATURE BASED ON PREVIOUS STUDIES}

Dividend policy has continuously been controversial because this is a dynamic issue. It is a significant issue not only due to the money involved, but also because dividend payments are recurring in nature. The policy of dividend payments is closely linked to most of the firm's investments and other financial rules and policies (Allen \& Michaely, 1995). Following the discovery of dividend irrelevance hypothesis by Miller and Modigliani (1961), a lot of work had been performed in the area of dividend policy determinants worldwide. The dividend irrelevance hypothesis argues that the policy of dividend payments has no impact on its market value and that the firm has no appropriate policy of dividends in a well-organized and perfect market where asymmetry information or taxes and transaction costs are not accessible. Although, all information in a perfect market is available for investor rapidly free of charge with no costs related to transaction or taxes involved (Vasicek \& McQuown, 1972) is far out of range. On the other hand, the primary purpose of a corporation is, debatably anticipated to increase the stockholder wealth (Block, Hirt, \& Short, 2000; Brealey \& Myers, 1996), but according to Block et al. (2000) this viewpoint is not a simple task because the management cannot directly affect the stock price but the willingness of investors is associated with stock price.

Shareholders usually experience trouble of unfavorable selection and threat in the case of ownership and control division. Many corporate claimholders faces trouble of asymmetric information that is apparent in divergence of interest. The conflicts of interest between shareholders and managers can be a result of finance available after funding all the positive NPV projects (Jensen, as cited in Abor and Bokpin (2010)). This conflict is the outcome of each party's preference to give priority for their own interest. As bondholders would desire shareholders to depart as much cash as possible in the corporation so that this cash can be offered to pay bondholders during financial distress time, while shareholders would desire to have extra / free cash for themselves (Sarmento, Kertahadi, \& Nuzula, 2014). It is argued that suppliers of the funds have less information about the company's cash flow as compared to the insiders such as managers. According to Jensen and Meckling (1976), the companies with high managerial ownership powers have low agency costs because of better arrangement of managerial and shareholder control. Also the companies that have large amount of shareholders are better capable of monitoring the managerial activities (Shleifer \& Vishny, 1986). The companies which are capable of generating sufficient income to fulfill their requirements of investment financing from their operations should use their free cash flow in the shape of dividend (Ardestani, Rasid, \& Mehri, 2013; Jensen, 1986). As 
suggested by Fama and Jensen (1983) if the company pays large amount of dividend to its shareholders than the agency problem can be resolved. This fact is supported by free cash flow hypothesis which refers that when dividend payments are made it decreases free cash flow because if dividends are increased, the ability of managers to practice wasteful activities will decrease and will benefit the stockholders (Sarmento et al., 2014).

The investment opportunity set is one of the most significant components of market value available to the corporation. Kallapur and Trombley (2001) refers that the company's investment opportunities influences in the way as the corporation is viewed by owners, creditors, managers, and investors. In recent years, the literature has given a great focus to examine the relationship between corporate policy choices and investment opportunities, including policies of compensation, dividend and financing (Abbott, 2001; Gaver \& Gaver, 1993; Jones \& Sharma, 2001; Kallapur \& Trombley, 1999; Smith Jr \& Watts, 1992). Jones and Sharma (2001) stated that company's investment or growth alternatives are represented by investment opportunity set but according to Myers (1977) the value of investment opportunities is based on the managers' discretionary expenditures. Myers (1977) further describes that the investment opportunities are future recognized potential projects which are profitable and company can determine and exploit them for fiscal rents. Smith Jr and Watts (1992) also commented that alternatives to make future investments can result in representing the element of the company's value.

The previous literature proposes that there is an association between dividend policy and investment opportunity set. According to Smith Jr and Watts (1992), the corporations that are expected to follow low dividend payout policy are those which have high investment opportunities, as investment and dividends indicate potential utilization of cash resources of the company (Gaver \& Gaver, 1993). There work was extended and modified by Jones and Sharma (2001) which discovered that firms which have high growth were linked with considerably low dividend yields. Gul and Kealey (1999) also discover that dividends and growth options have a negative relationship. Abbott (2001) also clarify that the companies which are facing expansion in investment opportunity set (decreases) and usually their policy of dividend payout is reduced (increase). The fact that companies which have book value lower than market value inclined to hold better investment opportunity set and will preserve more money to fund these investments, therefore documenting ratios having low dividend payout (Amidu \& Abor, 2006; Collins, Saxena, \& Wansley, 1996; Lloyd, Jahera, \& Page, 1985; Rozeff, 1982). Additionally, the firms with high investment opportunities should pay low dividend and used by firms to increase the profitable investment (Deshmukh, 2005). This is backed by Yudiana and Yadnyana (2016) findings, which suggests that investment opportunity set has a negative impact on dividends. Whereas, Ardestani et al. (2013) revealed different outcomes that investment opportunity set had a positive influence on cash dividend. Though, Purnami, Diah, and Artini (2015) discovered that investment opportunity set had no relationship with cash dividend, which was supported by Paramitha and Arfan (2017). 


\section{METHODOLOGY}

This article explores mainly the association of investment opportunity set and dividend policy. In order to assess the relevant research-work, the current study employed systematic reviews of literature method to analyze the previous literature (Jesson, Matheson, \& Lacey, 2011). This review process summed up all the related articles in the literature and offers an insight into this area of research. The template of PRISMA flowchart is utilized to explain the overall procedure of selection and rejections of studies. Moreover, this flowchart helps the investigator to enhance the review paper's reporting.

The current study utilized the published studies on Scopus database and the keywords used to find out the literature was "investment opportunity set" AND "Dividend". The total number of 23 articles were revealed and imported in excel sheets. Additionally, this study includes only articles published in "English" language. Moreover, hand search process is also used to search literature articles on Google Scholar, which is considered as one of the renowned database by researchers in various fields (Xiao \& Watson, 2017). The 14 articles were screened out from Google Scholar and were added to the existing excel sheet. However, during screening process we found different blogs linked to this topic, which were omitted because these sources are regarded as prejudicial and unreliable. After merging the articles extracted from Scopus and Google Scholar databases. The duplicates recorded were removed. Next, the records were screened based on titles, abstracts and fulltext according to inclusion and exclusion criteria. The final 28 articles were included in the review for analysis purpose. These all steps for systematic review of literature were carried out based on PRISMA flowchart and is shown in Fig. 1.

The inclusion and exclusion criteria is vital for screening the best possible records for the study. The studies published related to the topic and in English language were included. The articles, review and conference papers were included, whereas, book chapters were excluded from this study. In order to ensure the quality assessment of this review, every kind of duplication was checked and records were reviewed in detail to guarantee the quality and that relevant articles are included in this study.

\subsection{PRISMA Flowchart}

All the above steps for systematic review of literature have been shown in PRISMA flowchart as follows. 


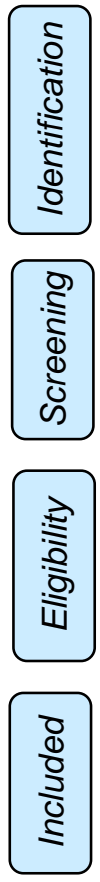

Records identified through searching SCOPUS database $(n=23)$

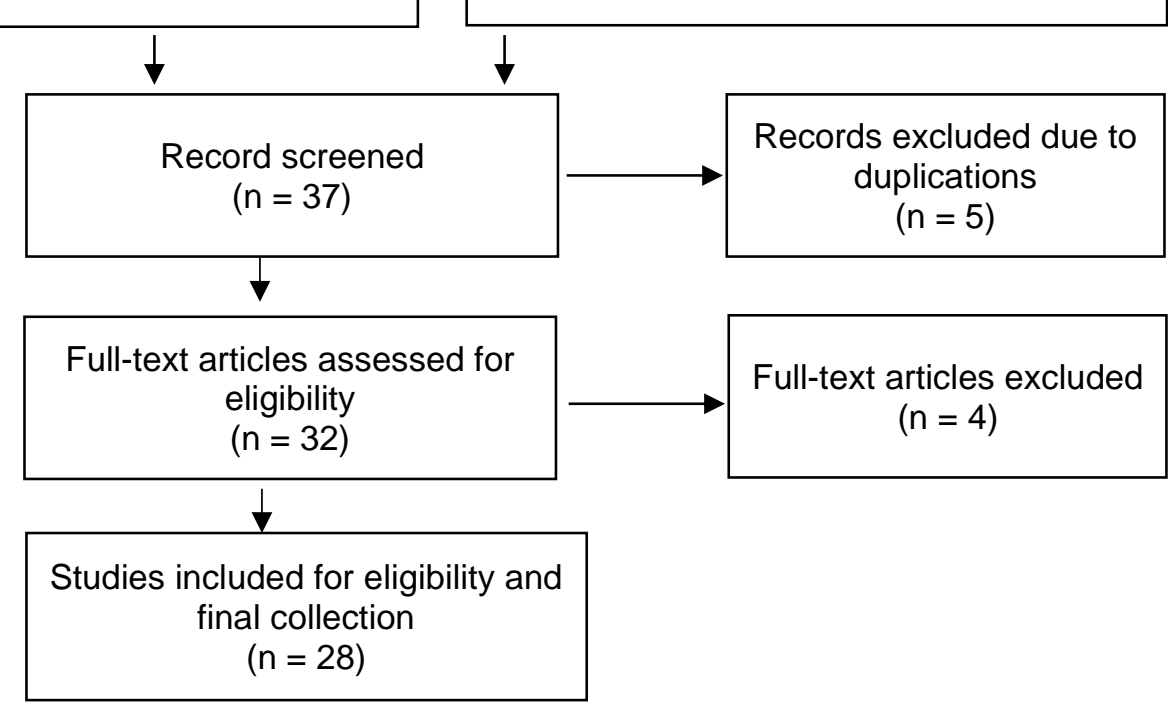

Fig. 1. PRISMA flowchart

\section{ANALYSIS AND DISCUSSION}

The final 28 selected papers are used for the analysis process. The analysis includes year based analysis, journal wise and nature of the articles.

\subsection{Publication Based on Year}

Fig. 2 illustrates the publications of papers based on years as number of articles published varies across each year. The figure imitates a gradual increase of studies from 2016 onwards and reaching highest in 2019.

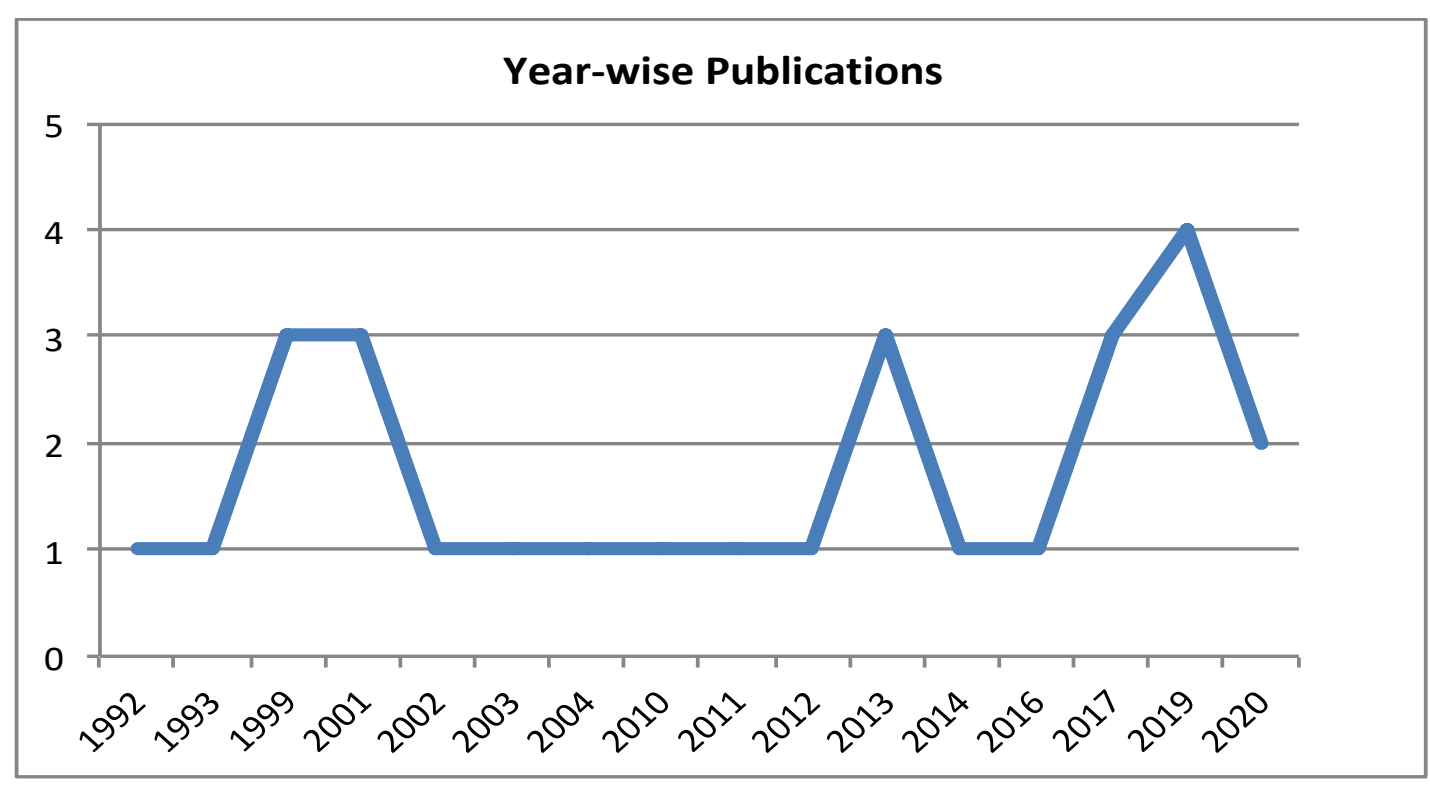

Fig. 2. Publications based on year 


\subsection{Journal Based publication}

The percentage of the journal signifies that in which journal majority of the studies concerning the topic of present study is published. Table 1 reveals the journal in which focuses and publishes on this topic is Managerial Finance obtaining 14.29\% (4 papers) and Review of Quantitative Finance and Accounting attaining 7.14 ( 2 papers). The remaining papers were published over 22 journals having one paper each.

Table 1. Journal based Publication

\begin{tabular}{lll}
\hline Journal Name & Number of articles & Percentage \\
\hline Managerial Finance & 4 & $14.29 \%$ \\
Review of Quantitative Finance and Accounting & 2 & $7.14 \%$ \\
Journal of Financial Economics & 1 & $3.57 \%$ \\
Journal of Accounting, Auditing \& Finance & 1 & $3.57 \%$ \\
Journal of Accounting and Economics & 1 & $3.57 \%$ \\
Studies in Economics and Finance & 1 & $3.57 \%$ \\
Journal of Corporate Finance & 1 & $3.57 \%$ \\
Pacific Basin Finance Journal & 1 & $3.57 \%$ \\
International Business Management & 1 & $3.57 \%$ \\
Asian Journal of Business and Accounting & 1 & $3.57 \%$ \\
\hline
\end{tabular}

\subsection{JouRnal ANALYSIS BASED ON CitATION}

The amount of articles published in each journal alone does not provide a reasonable basis for assessing journals, since the outcomes of each article is different. Therefore, the effects of journal publications on subsequent studies must be taken into account when inferring the findings mentioned in session 3.2. To resolve this matter, we use citations record for each journal. The analysis based on citation is the most widely utilized technique for assessing publication significance. The mechanism of this analysis is to sum-up number of times that other journal studies have cited your article (Ding \& Cronin, 2011; Xu et al., 2018). Table 2 denotes the citation and citation rank of the journals. Based on final 28 articles, the highest cited journal concerning this study topic was Journal of Financial Economics followed by Journal of Accounting and Economics. In general, the result vary based on citation analysis from the analysis outcome of previous section 3.2.

Table 2. Journal Analysis based on Citation

\begin{tabular}{llll}
\hline Journal Name & Number of articles & Citation & Citation Rank \\
\hline Managerial Finance & 4 & 52 & 3 \\
Review of Quantitative Finance and Accounting & 2 & 42 & 5 \\
Journal of Financial Economics & 1 & 1657 & 1 \\
Journal of Accounting, Auditing \& Finance & 1 & 24 & 8 \\
Journal of Accounting and Economics & 1 & 586 & 2 \\
Studies in Economics and Finance & 1 & 34 & 7 \\
Journal of Corporate Finance & 1 & 37 & 6 \\
Pacific Basin Finance Journal & 1 & 51 & 4 \\
\hline
\end{tabular}




\begin{tabular}{llll}
\hline International Business Management & 1 & 4 & 9 \\
Asian Journal of Business and Accounting & 1 & 1 & 10 \\
\hline
\end{tabular}

\subsection{Publication Document Type}

Fig. 3 exhibits the publication document type i.e. whether study published is either conference paper or journal article. The figure shows that rate of publication in journal is ranked highest (89\%) as compared to conference paper (11\%) because academicians and researchers regard the information and findings of publication in journals as more significant (Hanafizadeh, Keating, \& Khedmatgozar, 2014; Nord \& Nord, 1995).

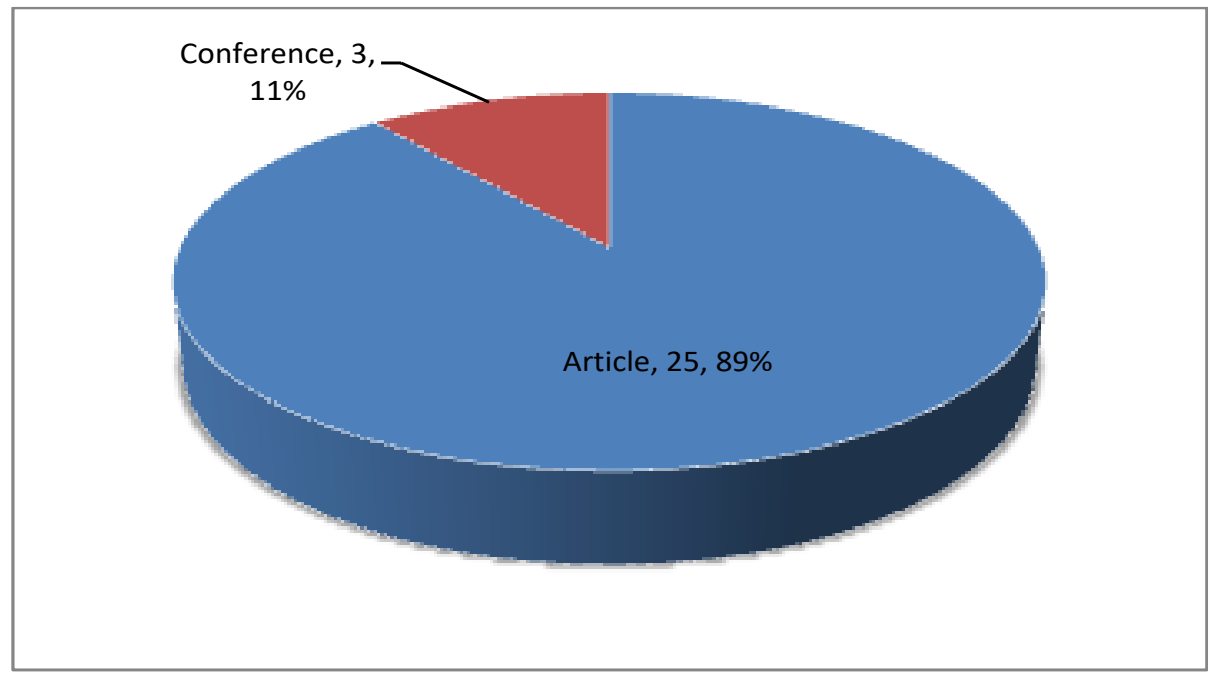

Fig. 3. Publication Document Type

\section{CONCLUSION}

This article main objective was to analyze the link between investment opportunity set and dividend policy and to take an overarching perspective of this study topic from the prevalent literature published. In this context, systematic review was done on final 28 selected articles on particular topic. This study contributes to the literature through the preparation of a concise map of the literature concerning studies related to the topic of this study. The research articles used in the current study are already published papers in the Scopus and Google Scholar database that completely comply with the reputations and standards related to respective area. Based on the previous literature, the studies have been analyzed on the basis of publication per year, which exhibits rising trend over the years, specifically from 2012 onwards, representing more than 50\% of total papers published. Additionally, the analysis was also done on the basis of publication in journal and citations. Based on journal publications, the findings suggest that Managerial Finance is the top journal with 4 papers published, followed by Review of Quantitative Finance and Accounting with 2 papers published. Whereas, based on citation, the highest rank journal was Journal of Financial Economics and second rank was Journal of Accounting and Economics. Moreover, the $89 \%$ of researchers trend were to publish their work in journalsbased articles on document-type. Furthermore, the limitation of this paper is that this systematic review only involves studies from Scopus and Google Scholar database. 
However, future studies can include articles from other sources like web of science etc., which may provide more interesting findings on this study topic.

\section{Reference:}

Abbott, L. J. (2001). Financing, dividend and compensation policies subsequent to a shift in the investment opportunity set. Managerial Finance.

Abor, J., \& Bokpin, G. A. (2010). Investment opportunities, corporate finance, and dividend payout policy: Evidence from emerging markets. Studies in economics and finance, 27(3), 180-194.

Aivazian, V., Booth, L., \& Cleary, S. (2003). Do emerging market firms follow different dividend policies from US firms? Journal of Financial Research, 26(3), 371-387.

Allen, F., \& Michaely, R. (1995). Dividend policy. Handbooks in operations research and management science, 9, 793-837.

Allen, F., \& Michaely, R. (2002). Payout policy. Forthcoming in. Handbook of Economics of Finance.

Amidu, M., \& Abor, J. (2006). Determinants of dividend payout ratios in Ghana. The Journal of risk finance, $7(2), 136-145$.

Ardestani, H. S., Rasid, S. Z. A., \& Mehri, R. B. M. (2013). Dividend payout policy, investment opportunity set and corporate financing in the industrial products sector of Malaysia. Journal of applied finance and banking, 3(1), 123.

Block, S., Hirt, G., \& Short, J. (2000). Fundamentals of financial management. New Delhi: Dow Jones and Company Chicopee.

Brealey, R., \& Myers, S. (1996). Principles of financial management: McGraw-Hill New York.

Brook, Y., Charlton Jr, W. T., \& Hendershott, R. J. (1998). Do firms use dividends to signal large future cash flow increases? Financial Management, 46-57.

Collins, M. C., Saxena, A. K., \& Wansley, J. W. (1996). The role of insiders and dividend policy: a comparison of regulated and unregulated firms. Journal of Financial and Strategic Decisions, 9(2), 1-9.

Deshmukh, S. (2005). The effect of asymmetric information on dividend policy. Quarterly Journal of Business and Economics, 107-127.

Ding, Y., \& Cronin, B. (2011). Popular and/or prestigious? Measures of scholarly esteem. Information processing \& management, 47(1), 80-96.

Fama, E. F., \& Jensen, M. C. (1983). Separation of ownership and control. The journal of law and Economics, 26(2), 301-325.

Gaver, J. J., \& Gaver, K. M. (1993). Additional evidence on the association between the investment opportunity set and corporate financing, dividend, and compensation policies. Journal of accounting and economics, 16(1-3), 125-160. 
Gul, F. A., \& Kealey, B. T. (1999). Chaebol, investment opportunity set and corporate debt and dividend policies of Korean companies. Review of Quantitative Finance and Accounting, 13(4), 401-416.

Hanafizadeh, P., Keating, B. W., \& Khedmatgozar, H. R. (2014). A systematic review of Internet banking adoption. Telematics and informatics, 31(3), 492-510.

Jensen, M. C. (1986). Agency costs of free cash flow, corporate finance, and takeovers. The American Economic Review, 76(2), 323-329.

Jensen, M. C., \& Meckling, W. H. (1976). Theory of the firm: Managerial behavior, agency costs and ownership structure. Journal of financial economics, 3(4), 305-360.

Jesson, J., Matheson, L., \& Lacey, F. M. (2011). Doing your literature review: Traditional and systematic techniques: Sage.

Jones, S., \& Sharma, R. (2001). The association between the investment opportunity set and corporate financing and dividend decisions: some Australian evidence. Managerial Finance.

Kallapur, S., \& Trombley, M. A. (1999). The association between investment opportunity set proxies and realized growth. Journal of Business Finance \& Accounting, 26(3-4), 505-519.

Kallapur, S., \& Trombley, M. A. (2001). The investment opportunity set: determinants, consequences and measurement. Managerial Finance.

Lloyd, W. P., Jahera, J. S., \& Page, D. E. (1985). Agency costs and dividend payout ratios. Quarterly Journal of Business and Economics, 19-29.

Miller, M. H., \& Modigliani, F. (1961). Dividend policy, growth, and the valuation of shares. the Journal of Business, 34(4), 411-433.

Myers, S. C. (1977). Determinants of corporate borrowing. Journal of financial economics, 5(2), 147-175.

Nord, J. H., \& Nord, G. D. (1995). MIS research: journal status assessment and analysis. Information \& Management, 29(1), 29-42.

Ooi, J. (2001). Dividend payout characteristics of UK property companies. Journal of Real Estate Portfolio Management, 7(2), 133-142.

Paramitha, C. B., \& Arfan, M. (2017). The effect of collateralizable asset, dispersion of ownership, free cash flow and investment opportunity set on cash dividend of manufacturing companies listed in Indonesia stock exchange. Proceedings of AlCS-Social Sciences, 7, 236-243.

Pruitt, S. W., \& Gitman, L. J. (1991). The interactions between the investment, financing, and dividend decisions of major US firms. Financial Review, 26(3), 409-430.

Purnami, A., Diah, K., \& Artini, L. G. S. (2015). Pengaruh Investment Opportunity Set, Total Asset Turn Over Dan Sales Growth Terhadap Kebijakan Dividen [The effect of 
investment opportunity set, total asset turn over and sales growth on dividend policy]. E-Jurnal Manajemen Universitas Udayana, 5(2), 1309-1337.

Rozeff, M. S. (1982). Growth, beta and agency costs as determinants of dividend payout ratios. Journal of Financial Research, 5(3), 249-259.

Sarmento, J. N., Kertahadi, \& Nuzula, N. F. (2014). The Effects of Investment Opportunity Set (Ios) and Corporate-financing on Dividend Payout Policy (a Study on Automotive and Components Companies Listed in Indonesia Stock Exchange Period 20092011). Jurnal Administrasi Bisnis, 13(2).

Shleifer, A., \& Vishny, R. W. (1986). Large shareholders and corporate control. Journal of political economy, 94(3, Part 1), 461-488.

Smith Jr, C. W., \& Watts, R. L. (1992). The investment opportunity set and corporate financing, dividend, and compensation policies. Journal of financial economics, 32(3), 263292.

Vasicek, O. A., \& McQuown, J. A. (1972). The efficient market model. Financial Analysts Journal, 71-84.

Woods, J. C., \& Randall, M. R. (1989). The net present value of future investment opportunities: its impact on shareholder wealth and implications for capital budgeting theory. Financial Management, 85-92.

Xiao, Y., \& Watson, M. (2017). Guidance on Conducting a Systematic Literature Review. Journal of Planning Education and Research, 0739456X17723971.

Xu, X., Chen, X., Jia, F., Brown, S., Gong, Y., \& Xu, Y. (2018). Supply chain finance: A systematic literature review and bibliometric analysis. International Journal of Production Economics.

Yudiana, I., \& Yadnyana, I. K. (2016). Pengaruh Kepemilikan Manajerial, Leverage, Investment Opportunity Set Dan Profitabilitas Pada Kebijakan Dividen Perusahaan Manufaktur [The effect of managerial ownership, leverage, investment opportunity set, and profitability on manufacturing companies dividend policy]. E-Jurnal Akuntansi Universitas Udayana, 15(1), 112-141. 